\title{
The Effect Of Family Characteristics And Parenting Patterns On The Nutritional Status Of Toddlers In Sigumpar Village, Sigumpar District, Toba Regency In 2020
}

\author{
Munarni \\ D3 Nursing Study Program, Arjuna STIKes, Indonesia
}

\begin{tabular}{l} 
Article Info \\
\hline Article history: \\
Received Oct 28, 2021 \\
Revised Nov 20, 2021 \\
Accepted Dec 23, 2021 \\
\hline
\end{tabular}

Keywords:

Parenting Pattern;

Nutritional Status;

Toddler;

Family Characteristics.

\begin{abstract}
Toddler age 12-59 months is a period when children really need nutrients in sufficient and balanced amounts. Lack of nutrients at this time can cause growth disorders. At this time too, the child is still completely dependent on the care and nurturing by his mother and family characteristics. The purpose of this study was to analyze the effect of family characteristics and parenting patterns on the nutritional status of children under five in Sigumpar Village, Sigumpar District. This type of research is a survey with the type of explanatory research. The population is all mothers who have children under five totaling 52 people. The collection of data on family characteristics, eating patterns using interviews guided by questionnaires and health parenting patterns using interviews guided by questionnaires. The nutritional status of children under five is based on the BB/TB index. Data analysis used multiple logistic regression test at a significance level of $95 \%$. The results showed that the nutritional status of children under five (1-5 years old) based on the BW/TB index was normal (40.4\%) and overweight (fat) $59.6 \%$. Family characteristics consisting of knowledge of mothers in the good category $65.4 \%$, higher education $75.0 \%$, family income $>1,200,000$ $(100 \%)$, working mothers $(59.6 \%)$, eating patterns applied by mothers to children good toddler $55.8 \%$. Likewise, the health pattern of children under five is good $61.5 \%$. There is an effect of parenting (eating and health) on the nutritional status of children under five.
\end{abstract}

This is an open access article under the CC BY-NC license.

\section{Corresponding Author:}

Munarni,

Diploma Nursing Study Program,

Arjuna STIKes, Indonesia

Jl. Y.P. Arjuna, Pintu Bosi, Lagu Boti, Toba, Sumatera Utara

Email: arnysweet84@gmail.com

\section{INTRODUCTION}

Nutritional and health status is one of the 3 (three) main factors that greatly determine the quality of Human Resources (HR), in addition to education and income (economy) [1]. The main challenge in the development of a nation is to build quality human resources that are healthy, intelligent and productive. Human development achievements as measured by the Human Development Index (HDI) have not shown encouraging results in the last three decades. In 2003, Indonesia's HDI was still low at 112 out of 174 countries, lower than neighboring countries. The low HDI is strongly 
influenced by the low nutritional status and health status of the population, this can be seen, among other things, from the still high infant mortality rate, namely 35 per thousand live births and the under-five mortality rate at 58 per thousand live births and the maternal mortality rate at 307 per hundred live births [2].

Nutritional problems are no longer considered simple. In fact, this has become one of the indicators of public health [3]. Of the 24 indicators that are the basis for determining the IPKM which are divided into three weight categories, namelys the absolute category with a weight of five as many as eleven indicators, the important category with a weight of four as many as five indicators, and the necessary category with a weight of three as many as eight indicators. For absolute categories, three of them are nutritional indicators, namely the prevalence of undernourished and malnourished children under five, the prevalence of stunted children under five, and the prevalence of underweight children under five.

This proves that the problem of nutrition is not a trivial problem. There are two types of problems that arise due to malnutrition, namely overnutrition and undernutrition [4]. Over nutrition in the last two decades has increased due to changes in people's lifestyles, especially in urban areas. Even the problem of overnutrition has become a polemic in developed countries. Nutrition can be judged more than body weight. From data compiled by WHO in 2008 it was stated that about 1.5 billion adults are overweight, 200 million adult men are obese, and more than 300 million women are obese. A 2008 study by the Centers for Disease Control in Atlanta conducted in the United States showed that almost one in five children aged 6-11 years and 18.1 percent of children aged 12-19 years were obese. In Indonesia alone in 2003, there were $2.24 \%$ of children under five who were overweight, while the data for the population over 15 years old showed that $10.3 \%$ were overweight.

Having healthy and smart children is the dream of every parent. To make it happen, of course, parents must always pay attention to their growth and development [5] [6]. Although the process of child growth and development takes place naturally, the process is very dependent on adults or parents. Moreover, the first five years (toddler) is an important period in children's growth and development and is a period that will determine their physical, psychological and intelligence formation [7]. A mother who plays an important role in the upbringing of her child, has a different parenting pattern. Because this is strongly influenced by factors that support it, including: mother's educational background, mother's occupation, mother's nutritional status, number of children, and so on [8].

The role of mothers in the growth and development of children is very dominant to nurture and educate children so that they grow and develop into quality children. The parenting style applied by the mother can affect the growth of the child, especially the nutritional status of the child. [9], found a positive correlation between the parenting style of the mother and the nutritional status of her child. The process of nurturing and educating children requires sufficient time, although nowadays it is developing that the most important parenting pattern is the quality, but quantity is needed in this case the time together between mothers and their children. It is clear that a mother has an important role in parenting to determine a good nutritional status for her children so that the child can grow and develop into a quality human being [10] [5].

The description of the nutritional status of children under five in North Sumatra in 2000 was $17.3 \%$ malnutrition and $9.16 \%$ malnutrition, in 2003 the prevalence of malnutrition was $18.59 \%$ and malnutrition was $8.82 \%$ in 2006 there was a decrease in the percentage of children under five with malnutrition by $1.02 \%$ to $7.8 \%$ but the percentage of undernourished children under five increased by $4.72 \%$ to $23.31 \%$. The prevalence of undernutrition and malnutrition in North Sumatra is still included in the high category so it needs to be watched out for because it tends to fluctuate from year to year [11] [12]. The results of the 2010 Basic Health Research, showed that the number of underfives was undernourished at $17.9 \%$. The problem of micro nutrients (micronutrient deficiency) or hidden hunger is still common in Indonesia [13].

The initial survey conducted by the researcher through the observations of researchers found that there were children under five who were overweight as much as 50\% of the children experienced 
excess nutrition, and interviews with the village head who said that Sigumpar village is a village where the average livelihood is farmers, and this village is a one of the villages that has a total of 216 families, with a population of 1,118 people.

\section{RESEARCH METHOD}

This research is a type of survey research with explanatory research type [14] [15] [16], namely research that explains the influence between independent variables (family characteristics and parenting patterns) with the dependent variable (nutritional status of children under five) in Sigumpar Village, Sigumpar District, Toba Regency.

\section{RESULTS AND DISCUSSIONS}

\subsection{Characteristics of Toddlers}

Characteristics of children under five include age, presented in Table 4.2 more aged 1 to 3 years $53.8 \%$ compared to those aged over 4 to 5 years $46.2 \%$. Meanwhile, the gender of children under five is the same between boys and girls.

Table 1. Distribution of the Characteristics of Toddlers who have Toddlers in Indonesia Sigumpar Village, Sigumpar District

\begin{tabular}{llcc}
\hline No & Toddler Characteristics & n & \% \\
\hline & Age & & \\
1 & 13 years old & 28 & 53,8 \\
2 & 4-5 years & 24 & 46,2 \\
\hline & Total & $\mathbf{5 2}$ & $\mathbf{1 0 0 , 0}$ \\
\hline & Gender & & \\
1 & Woman & 26 & 50,0 \\
2 & Man & 26 & 50,0 \\
\hline & Total & $\mathbf{5 2}$ & $\mathbf{1 0 0 , 0}$ \\
\hline
\end{tabular}

Relationship between Mother's Knowledge and Nutritional Status of Toddlers in Sigumpar Village, Sigumpar District, Toba Regency.In Table 4 . Of the 34 mothers who had good knowledge, 18 people (52.9\%), had normal nutritional status, 26 people (47.1\%). Meanwhile, 18 mothers with sufficient knowledge have normal nutritional status (16.7\%) and 15 people (83.3\%).

The results of the Chi Square statistical test obtained $\mathrm{p}$ value $=0.011>0.05$. This means that there is a relationship between mother's knowledge and the nutritional status of children under five in Sigumpar Village, Sigumpar District, Toba Regency.

Table 2. Relationship between Mother's Knowledge and Nutritional Status of Toddlers in Sigumpar Village, Sigumpar District, Toba Regency

\begin{tabular}{|c|c|c|c|c|c|c|c|}
\hline \multirow{3}{*}{ Mother's Knowledge } & \multicolumn{4}{|c|}{ Toddler Nutritional Status } & \multicolumn{2}{|c|}{ Total } & \multirow{3}{*}{ P-Value } \\
\hline & \multicolumn{2}{|c|}{ Normal } & \multicolumn{2}{|c|}{ Fat } & \multirow{2}{*}{$\mathbf{n}$} & \multirow{2}{*}{$\%$} & \\
\hline & $\mathbf{n}$ & $\%$ & $\mathbf{n}$ & $\%$ & & & \\
\hline Well & 18 & 52,9 & 26 & 47,1 & 34 & 100 & \multirow{3}{*}{$P=0,011$} \\
\hline Currently & 3 & 16,7 & 15 & 83,3 & 18 & 100 & \\
\hline Not good & o & o & o & o & o & $\mathrm{o}$ & \\
\hline
\end{tabular}

Relationship between Mother's Education and Nutritional Status of Toddlers in Sigumpar Village, Sigumpar District, Toba Regency. In Table 5. Of the 39 mothers with higher education, 19 people $(48.7 \%)$ had normal nutritional status, 20 people $(51.3 \%)$ had obese nutritional status. Meanwhile, 
there are 13 mothers with middle education, 2 people (15.4\%) normal nutritional status and 11 people $(84.6 \%)$.

The results of the Chi Square statistical test obtained $p$ value $=0.023>0.05$. This means that there is a relationship between maternal education and the nutritional status of children under five in Sigumpar Village, Sigumpar District, Toba Regency.

Table 3. Relationship between Mother's Education and Nutritional Status of Toddlers in Sigumpar Village, Sigumpar District, Toba Regency

\begin{tabular}{|c|c|c|c|c|c|c|c|}
\hline \multirow{3}{*}{ Education } & \multicolumn{4}{|c|}{ Toddler Nutritional Status } & \multirow{2}{*}{\multicolumn{2}{|c|}{ Total }} & \multirow{3}{*}{ P-Value } \\
\hline & \multicolumn{2}{|c|}{ Normal } & \multicolumn{2}{|c|}{ Fat } & & & \\
\hline & $\mathbf{n}$ & $\%$ & $\mathbf{n}$ & $\%$ & $\mathbf{n}$ & $\%$ & \\
\hline Tall & 19 & 48,7 & 20 & 51,3 & 39 & 100 & $P=0,023$ \\
\hline Intermediate & 2 & 15,4 & 11 & 84,6 & 13 & 100 & \\
\hline
\end{tabular}

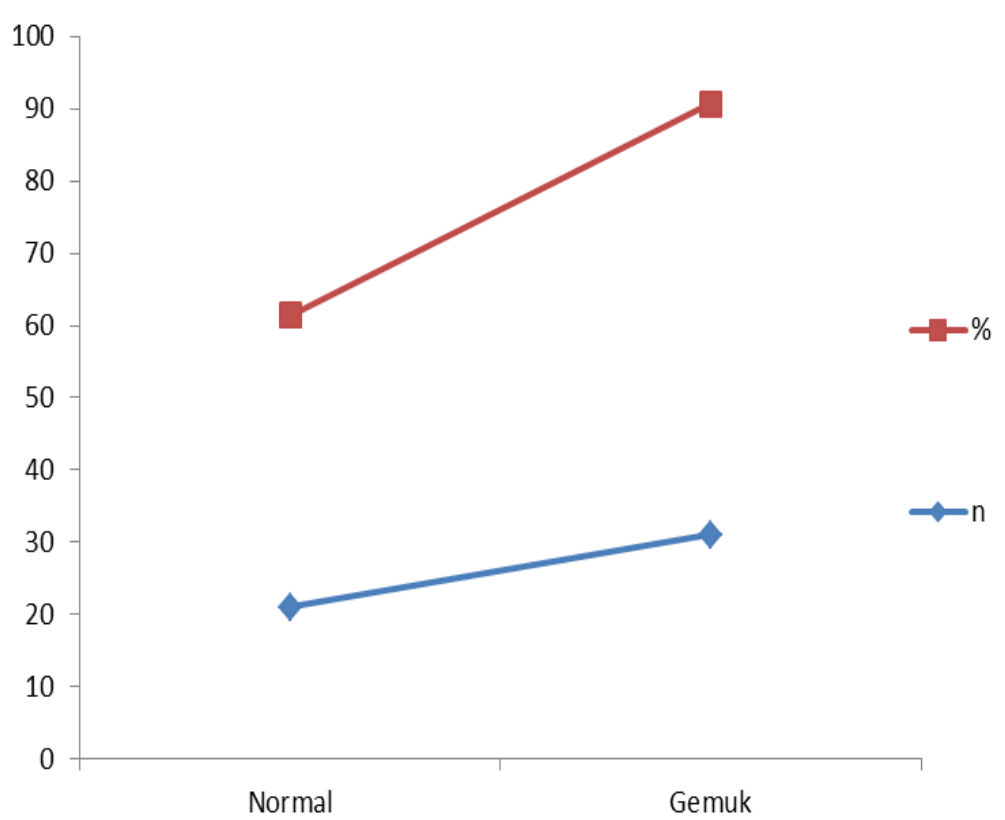

Figure 1. Distribution of the Nutritional Status of Toddlers based on the BB/TB Index in Sigumpar Village, Sigumpar District, Toba Regency

3.2. The Effect of Family Characteristics on the Nutritional Status of Toddlers in sigumpar Village, Sigumpar District, Toba Regency

Based on the logistic regression test, there was a significant effect of mother's knowledge on the nutritional status of children under five with $p=0.034>0.05$. The results of this research from the field of nutrition knowledge they get from health magazines, especially Indonesian recipe magazines, so that parenting patterns, especially feeding in the preparation of the menu, become more varied.

Based on the logistic regression test, there was a significant effect of mother's education on the nutritional status of children under five with $\mathrm{p}=0.017>0.05$. From these data, it can be seen that the higher the mother's education, the better the child's upbringing pattern and the better the child's nutritional status.

Higher education provides possibilities for increased knowledge, information, awareness of health and nutrition. In the sense that the higher the education of the mother, it is easier to understand and absorb health information and to apply it more quickly and easily in family life. This is in line with [17] statement that the level of education also determines whether or not a person 
easily absorbs and understands the knowledge he acquires. The higher the mother's education, the higher the mother's ability to absorb practical knowledge and non-formal education, especially through television, health magazines, radio and others. According to [18], it was revealed that the socio-economic factors of the community (education level) had an effect on the nutritional status of children under five. Mothers with low education are less able to understand or analyze health information given to them, compared to mothers with high knowledge. The behavior of mothers in providing health care through environmental hygiene and poor under-five nurses has an impact on the nutritional status of toddlers. Parenting factors for toddlers include eating and health parenting that affect the nutritional status of toddlers.

Based on the logistic regression test, there was a significant effect of mother's work on the nutritional status of children under five with $\mathrm{p}=0.019>0.05$. Time outside the mother's house is basically related to work, the more time outside the mother's house, the child will get less attention, so it will affect the child's eating pattern so that the child's food no longer meets a balanced menu.

3.3. The Effect of Parenting for Toddlers on the Nutritional Status of Toddlers in Sigumpar Village, Sigumpar District

Parenting for toddlers which aims to fulfill physical and biomedical needs in increasing optimal growth of toddlers. The behavior of mothers in applying parenting patterns to toddlers consists of eating patterns and health parenting patterns. According to [19] that in the household, the nutritional status of children under five is influenced by the mother's ability to provide food, both in quantity and type and parenting is also influenced by education, work, behavior and household health conditions. One of the causes of malnutrition in children under five is the result of inadequate parenting.

According to [18], it was revealed that the socio-economic factors of the community (education level) had an effect on the nutritional status of children under five. Mothers with low education are less able to understand or analyze health information given to them, compared to mothers with high knowledge. The behavior of mothers in providing health care through environmental hygiene and poor under-five nurses has an impact on the nutritional status of toddlers. Parenting factors for toddlers include eating and health parenting that affect the nutritional status of toddlers.

Based on the results of the multiple logistic regression test, it shows that the research variable, namely the parenting pattern of children under five (eat parenting, health parenting has an influence $(p>0.05)$, on the nutritional status of children under five in Sigumpar Village. The dominant pattern of parenting is eating, because the regression coefficient (B) is larger, namely 3.526, so it can be concluded that mothers who practice good parenting have 33,987 times the possibility that their children's nutritional status will be better (normal) compared to mothers who do bad parenting.

\subsection{The Influence of Eating Parenting on the Nutritional Status of Toddlers in Sigumpar Village, Sigumpar District, Toba Regency}

Based on the logistic regression test, there was a significant effect of eating parenting on the nutritional status of children under five with a value of $p=0.014>0.05$, with eating parenting patterns given by mothers at the Sigumpar Village more categorized as good $(55,8 \%)$. According to [20], food will affect the growth and physical and mental development of children. Therefore, the type of food must be able to meet the nutritional needs of children.

Giving food to toddlers is related to the variety of foods that must be given to toddlers repeatedly, starting with staple and additional foods. A complete diet is a food consisting of staple food, rice, side dishes, vegetables, fruit and breast milk (milk).

Food preparation must be able to meet the nutritional needs of toddlers. Food arrangements, namely food arrangements must be adapted to the age of toddlers in addition to getting nutrition, food arrangements are also good for maintenance, recovery, growth, development and physical activity.

The results of research in the field show that the behavior of mothers in providing food parenting to their toddlers tends to be good, but this is not accompanied by implementation at

The Effect Of Family Characteristics And Parenting Patterns On The Nutritional Status Of Toddlers In Sigumpar Village, Sigumpar District, Toba Regency In 2020 (Munarni) 
home, because in general children are fed by caregivers, where caregivers do more work at home than the mother, although the mother still monitors through communication by calling the caregiver. Children also if they don't want to eat, they are persuaded, while bringing them to the front of the house, while playing, but if they eat a little, they are given enough to drink milk, causing the nutritional status of children to experience more nutrition. However, if the child does not want to eat, the child is enough to be given ready-to-eat food, formula milk, snacks, chocolate and the child is taken to eat out of the house.

Based on the results of research in the field, children aged 1-3 years, as many as 28 respondents, are categorized as good in feeding. Based on the results of the answers, respondents said that they had introduced adult food to children, fed children 3 times a day, the food served had varied, for example rice, vegetables, fish, gave 3 glasses of formula milk a day, even excess, provided snacks $2 \mathrm{x}$ a day even for example giving snacks such as pergedel, tofu contents, or some kind of fried food, toast, and mother also giving ice cream, juice which is always served every morning, and if the child does not want to eat, the child is invited to play in front of the house. However, in terms of still giving breast milk to children under five, almost all mothers do not give breast milk, on average they give formula milk, due to busy work reasons. Respondents who have children under five years of age 4-5 years, as many as 24 respondents, have a parenting pattern that tends to eat less well.

Based on the results of the respondents' answers, the mother does not accompany the child to eat, because the mother thinks the child can eat alone, the child drinks formula milk is up to the child's taste, tends to always be asked by the child, excessive is also okay, giving snacks is also given excessively, take itself from the refrigerator, where in the refrigerator all children's food needs are available. Some respondents said that their children could be fat because of hereditary factors from other families, and some said that it was very unethical if the children of rich people were malnourished. This indicates that they pay less attention to the care of their children and do not realize that these actions can affect the growth and development of children which will affect the intelligence, creativity and behavior of children in the future.

3.5. The Effect of Health Parenting on the Nutritional Status of Toddlers in Sigumpar Village, Sigumpar District

Based on the logistic regression test, there was a significant effect of health parenting on the nutritional status of children under five with $\mathrm{p}$ value $=0.025>0.05$, with the pattern of health care for children under five in Sigumpar Village, Sigumpar District more in the good category (61.5\%). According to [21], the behavior of mothers in dealing with sick toddlers and programmed health monitoring is a pattern of health care that greatly affects the nutritional status of children under five. [19] adds that at the household level, nutritional status is influenced by the household's ability to provide food, both in sufficient quantity and type, and parenting, which is influenced by education, behavior and household health conditions. One of the causes of malnutrition in children under five is the result of inadequate parenting.

The results of the study also found that the pattern of health care had been implemented well, it was proven that the family had their own pediatrician. This is also supported by mothers who provide medicines at home, and mothers who always give vitamins to their children, even though their appetites increase, they are still given vitamins.

\section{CONCLUSION}

Based on the results of research and discussion, the following conclusions can be drawn: (1). The nutritional status of children under five that was found consisted of normal nutrition $40.4 \%$ and over nutrition 59.6\%. (2). Family characteristics consisting of good knowledge of mothers (65.4\%), higher education $(75.0 \%)$, mothers who work more (59.6\%), family incomes are all above the minimum wage (> IDR 1,200,00o,-). (3). The feeding pattern applied by mothers to children under five is classified as good (55.8\%). (4). The pattern of health care applied by mothers to children under five is classified as good (61.5\%). (5). There is an effect of family characteristics (mother's knowledge, 
education, occupation), eating and health care patterns on the nutritional status of children under five. Parenting eating patterns more dominantly affect the nutritional status of children under five.

\section{ACKNOWLEDGEMENTS}

Praise and gratitude the author prays to the presence of God Almighty, for his blessing the author was able to complete this research with the title "The Effect of Family Characteristics and Parenting Patterns on the Nutritional Status of Toddlers in Sigumpar Village, Sigumpar District, Toba Regency in 2020. This research is structured as the Tridharma of Higher Education, namely part Research at the $\mathrm{D}_{3}$ Nursing Study Program, STIKes Arjuna.

During the research process and the completion of this research, the author received a lot of help, guidance and support from many parties. Therefore, on this occasion the author would like to express his deepest gratitude and appreciation to:

a. The Chairperson of the T.P Arjuna Laguboti Foundation Management and their staff who have provided the opportunity and facilities to conduct this research.

b. Mrs. Head of STIKes Arjuna who has given permission and support during the implementation of this research

c. Head of the $D_{3}$ Nursing Study Program of STIKes Arjuna who has given permission and support during the implementation of this research

d. Mr. Sigumpar Village Head and all his staff who have given permission to carry out this research

e. All respondents who have been willing to assist in filling out the research questionnaire

f. Friends who cannot be mentioned one by one for their help and support.

[1] G. Mwabu, M. Ainsworth, and A. Nyamete, "Quality of medical care and choice of medical treatment in Kenya: an empirical analysis,” J. Hum. Resour., pp. 838-862, 1993.

[2] A. Azwar, "Kecenderungan masalah gizi dan tantangan di masa datang. Disampaikan Pada Pertemuan Advokasi Program Perbaikan Gizi Menuju Keluarga Sadar Gizi," no. September, pp. 1-16, 2004.

[3] K. G. Grunert and J. M. Wills, "A review of European research on consumer response to nutrition information on food labels," J. Public Health (Bangkok)., vol. 15, no. 5, pp. 385-399, 2007.

[4] I. Kolčić, "Double burden of malnutrition: A silent driver of double burden of disease in low-and middle-income countries," J. Glob. Health, vol. 2, no. 2, 2012.

[5] K. R. Ginsburg and C. on P. A. of C. and F. Health, "The importance of play in promoting healthy child development and maintaining strong parent-child bonds," Pediatrics, vol. 119, no. 1, pp. 182-191, 2007.

[6] S. Harkness and C. M. Super, "Themes and variations: Parental ethnotheories in Western cultures," Parent. beliefs, Behav. parent-child relations A cross-cultural Perspect., pp. 61-79, 2006.

[7] Dina Agoes Sulistijani, Menjaga kesehatan bayi dan balita, I. Jakarta: Puspa Swara, 2001.

[8] J. Roelofs, C. Meesters, M. Ter Huurne, L. Bamelis, and P. Muris, "On the links between attachment style, parental rearing behaviors, and internalizing and externalizing problems in non-clinical children,” J. Child Fam. Stud., vol. 15, no. 3, p. 319, 2006.

[9] M. B. Structures, "KECENDERUNGAN PENGETAHUAN GIZI IBU DAN POLA ASUH PADA BALITA GIZI KURANG DI WILAYAH KERJA PUSKESMAS KLUNGKUNG I."

[10] L. Genesoni and M. A. Tallandini, "Men's psychological transition to fatherhood: an analysis of the literature, 1989-2008," Birth, vol. 36, no. 4, pp. 305-318, 2009.

[11] Badan Penelitian dan Pengembangan Kesehatan Depkes RI, "Laporan Hasil Riset Kesehatan Dasar (RISKESDAS) Provinsi Sumatera Utara," pp. 1-267, 2009.

[12] W. Hanandita and G. Tampubolon, "The double burden of malnutrition in Indonesia: Social determinants and geographical variations," SSM-population Heal., vol. 1, pp. 16-25, 2015.

[13] Menkes, "Indonesian_Minstry_of_Health_Strategic_Plan_2010-2014.Pdf." 2010.

[14] K. L. Barriball and A. E. While, "Non-response in survey research: a methodological discussion and development of an explanatory model," J. Adv. Nurs., vol. 30, no. 3, pp. 677-686, 1999.

[15] A. Pinsonneault and K. Kraemer, "Survey research methodology in management information systems: an assessment," J. Manag. Inf. Syst., vol. 10, no. 2, pp. 75-105, 1993.

[16] G. G. Gable, "Integrating case study and survey research methods: an example in information systems," Eur. J. Inf. Syst., vol. 3, no. 2, pp. 112-126, 1994.

[17] L. J. HARPER, B. J. Deaton, J. A. Driskel, and Suharjo, Pangan, gizi dan pertanian, Cetakan 2. Jakarta: UIPress, 1986. 
[18] Yusrizal, "Analysis of difficulty level of physics national examination's questions," J. Pendidik. IPA Indones., vol. 5, no. 1, pp. 140-149, 2016, doi: 10.15294/jpii.v5i1.5803.

[19] Soekirman, Ilmu gizi dan aplikasinya untuk keluarga dan masyarakat. Jakarta: Ditjen DIKTIDEPDIKNAS, 2000.

[20] F. X. T. Sunarti | Adonis, Pola pengasuhan anak secara tradisional di Kelurahan Kebagusan Daerah Khusus Ibukota Jakarta. Jakarta: Departemen Pendidikan dan Kebudayaan, 1989.

[21] T. P. Budi, Riset Statistik Parametrik. Yogyakarta: Andi, 2006. 